\title{
Present scenario of hemoglobinopathies in West Bengal, India: An analysis of a large population
}

Background: To find out the prevalence of hemoglobinopathies by screening large population in West Bengal from Eastern India. Materials and Methods: A total of 50,487 subjects are screened for hemoglobinopathies from June 2010 to August 2013. A $2.5 \mathrm{ml}$ of venous blood samples were collected in the tri-potassium EDTA vacuum container from each subject and tested with automated blood cell counter (Sysmex KX21) for red cell indices. Diagnosis of hemoglobinopathies was done by VARIANT ${ }^{\mathrm{TM}}$ (Bio-Rad Laboratories, Hercules, CA, USA) high performance liquid chromatography (HPLC). Results: Out of 50,487 cases, 44,620 (88.38\%) had normal and $5,867(11.62 \%)$ showed abnormal hemoglobin fractions on HPLC. Of these, 5,180(10.26\%) were heterozygotes (traits) and $687(1.36 \%$ ) cases were either homozygotes or compound heterozygote for different types of hemoglobinopathies. The following hemoglobinopathies were present: $\beta$-thalassemia trait $6.61 \%, \mathrm{HbE}$ trait $2.78 \%$, sickle cell trait $0.56 \%$, HbD-Punjab trait $0.21 \%$, $\beta$-thalassemia major $0.73 \%, \mathrm{HbEE} 0.05 \%$, compound heterozygosity for $\mathrm{HbE}-\beta$-thalassemia $0.42 \%$, and $\mathrm{HbS}-\beta$-thalassemia $0.15 \%$. Conclusion: Among the hemoglobinopathies, $\beta$-thalassemia trait $(6.61 \%)$ and $\mathrm{HbE}$ trait $(2.78 \%)$ are prevalent in rural Bengal.

Key words: Hemoglobinopathies, HPLC, prevalence, West Bengal

Prakas Kumar Mandal, Suman Kumar Maji', Tuphan Kanti Dolai

Department of Hematology, N.R.S. Medical College and Hospital, Kolkata,

${ }^{1}$ Department of Microbiology, Vidyasagar University,

West Midnapore - 721 101, West Bengal, India

Address for the Correspondence: Dr. Prakas Kumar Mandal, $8 \mathrm{c} / 1 / \mathrm{N}$, Roy Para Road, First Floor, Kolkata - 700 050, India. E-mail:prakas70@gmail.com

\begin{tabular}{|l|}
\hline Access this article online \\
\hline Website: www.ijmedph.org \\
\hline DOI: 10.4103/2230-8598.144127 \\
\hline Quick response code: \\
\hline
\end{tabular}

\section{INTRODUCTION}

Thalassemia and other hemoglobinopathies are genetic disorders of hemoglobin, which can be prevented by population screening and offering genetic counseling. In India it is estimated that there are over 25 million carriers of this disease. ${ }^{[1]}$ Beta-thalassemia ( $\beta$-thalassemia), sickle cell anemia, E-beta thalassemia and hemoglobin D Punjab are the common hemoglobinopathies in the world including India. About $4.5 \%$ of world population is affected by hemoglobinopathies. ${ }^{[2]}$ The estimated prevalence of thalassemia in India is 3-8\%. ${ }^{[3]}$ In a recent study, the carrier rate in rural West Bengal is shown to be around $16.23 \%$ in general population. ${ }^{[4]}$ It was recorded that yearly 10,000 children with $\beta$-thalassemia major are born in India which comprise $10 \%$ of the total number in the World. ${ }^{[5]}$ Another report has revealed that 7,500-12,000 babies would be born with $\beta$-thalassemia major in India each year. ${ }^{[6]}$ When different $\mathrm{Hb}$ variants are in heterozygous state, they can interact with others and may lead to serious homozygous or compound heterozygous Hb variants in the offspring. Double or compound heterozygous states between certain variants can lead to clinical manifestations. During the last few years a group of hematologists and geneticists including professional technical staff of the many countries endow with efforts for prevention and control of thalassemia to increase their good practice in the control and management of thalassemia in Asia for providing a central forum, interacting with governments and international health agencies to give support for this objective. The present work was carried out to evaluate the prevalence of $\beta$-thalassemia, $\mathrm{HbS}, \mathrm{HbD}, \mathrm{HbE}$ by generating awareness and successful screening programme for carrier detection which is important to identify asymptomatic carriers who have an increased risk of having a child with thalassemia. There is no sufficient data from rural Bengal from Eastern India. This will be the first epidemiological study on a vast population from rural Bengal. 


\section{MATERIALS AND METHODS}

Thalassaemia Society of Midnapore District conducted this pilot study from June 2010 to August 2013. A total of 50,487 cases were subjected to study from different districts of rural areas of West Bengal by arranging camps and awareness programmes in the villages. The society served their services in schools, colleges and university also for screening of individuals for detection of different hemoglobinopathies. The technical staffs collected $2.5 \mathrm{ml}$ of venous blood in the tri-potassium EDTA vacuum container from each subject. They were informed and written consent was collected in the presence of health personnel and community leaders. Collected samples were transported under cool conditions to the laboratory within 3-6 hrs of collection.

The blood samples were tested by automated blood cell counter (Sysmex KX21; Sysmex Corporation, Kobe, Japan) for red cell indices. Peripheral blood smear examination, red cell indices and other parameters are also considered for diagnosis of hemoglobinopathies. Diagnosis of hemoglobinopathies was done by VARIANT ${ }^{\mathrm{TM}}$ (Bio-Rad Laboratories, Hercules, CA, USA) high performance liquid chromatography (HPLC). HbA2 value of $3.3 \%$ to $3.8 \%$ was considered as borderline and a cut-off of over $3.9 \%$ was taken for diagnosis of $\beta$-thalassemia trait. ${ }^{[4,7-9]}$ In very few cases, which were not interpreted by HPLC, were confirmed by amplification refractory mutation system, polymerase chain reaction (PCR-ARMS) technique. ${ }^{[10]}$

\section{RESULTS}

A total 50,487 cases were studied. Of these, 44,620 (88.38\%) had normal and 5,867 (11.62\%) showed abnormal hemoglobin fractions on HPLC. The distributions of different traits and hemoglobinopathies are shown in Tables 1 and 2. After analysis, 5,180 cases $(10.26 \%)$ were detected as carriers and $687(1.36 \%)$ cases were either homozygotes or compound heterozygote for different kinds of hemoglobinopathies. Out of 5180 cases of traits; 5,132 cases had shown $\beta$-thalassemia trait, $6.61 \%$, HbE trait, $2.78 \%$, sickle cell trait, $0.56 \%$, HbD-Punjab trait, $0.21 \%$. Thirty four cases $(0.07 \%)$ had shown hereditary persistence of fetal hemoglobin (HPFH) traits and 14 cases $(0.03 \%)$ had shown other rare hemoglobin variants which included 6 cases of Hb-Lepore trait. Amongst the homozygotes or compound heterozygotes, the distribution of cases was as follows: $\beta$-thalassemia major (368 cases) $0.73 \%$, HbEE (26 cases) $0.05 \%$ and compound heterozygosity for HbE- $\beta$-thalassemia (213 cases) and HbS- $\beta$-thalassemia (75 cases) were $0.42 \%$ and $0.15 \%$ respectively.

\section{DISCUSSION}

Hemoglobinopathies are a major health problem all over the world including India and Southeast Asian region. ${ }^{[11]}$ In the present study, out of 50,487 cases, 44,620 (88.38\%) had normal and $5867(11.62 \%)$ showed abnormal hemoglobin fractions on HPLC. In a recent study from Western India, out of 7261 cases, 1615 (22.24\%) cases showed

\begin{tabular}{lcc}
$\begin{array}{l}\text { Table 1: Distribution of different heterozygotes } \\
\text { (traits) in the present study }(\boldsymbol{n}=\mathbf{5 0 , 4 8 7})\end{array}$ \\
\hline Type & Number & Percentage \\
\hline Beta trait & 3339 & 6.61 \\
E trait & 1403 & 2.78 \\
S trait & 284 & 0.56 \\
D trait & 106 & 0.21 \\
HPFH & 34 & 0.07 \\
Others & 14 & 0.03 \\
Total & 5180 & 10.26 \\
\hline
\end{tabular}

\begin{tabular}{lcc}
$\begin{array}{l}\text { Table 2: Distribution of different homozygotes } \\
\text { or compound heterozygotes in the present study } \\
(\boldsymbol{n}=\mathbf{5 0 , 4 8 7 )}\end{array}$ & Number & Percentage \\
\hline Types & 368 & 0.73 \\
$\beta$-thalassemia major & 213 & 0.42 \\
HbE- $\beta$-thalassemia & 26 & 0.05 \\
Hb E disease & 05 & 0.01 \\
HbD-Punjab disease & 75 & 0.15 \\
HbS- $\beta$-thalassemia & 687 & 1.36 \\
Total & &
\end{tabular}

abnormal Hb fractions. ${ }^{[12]}$ Higher cases of abnormal hemoglobin fractions on HPLC from referral center in Western India probably does not reflect population-based data as shown in the present study with much lower overall prevalence, done in a rural population from Eastern India.

The largest screening programme for thalassemia using the HPLC system in the population has been carried out in Gujarat, India by the Indian Red Cross Society in Ahmedabad and other cities. From 2004 to 2010, they screened 370,117 subjects for carrier status, among whom there were 173,112 students, 45,000 youths and 8,377 pregnant women. Carrier rate has varied from $4.3 \%$ to $5.0 \% .{ }^{[13]}$

In the present study, the prevalence of $\beta$-thalassemia trait was $6.61 \%$ making this the major hemoglobinopathy in West Bengal, India. The high prevalence rate of $\beta$-thalassemia trait is found in more than 60 countries with carrier population up to 150 million. ${ }^{[1]}$ The distribution of the $\beta$-thalassemia gene is not uniform in Indian subcontinent. ${ }^{[1,3]}$ The prevalence of $\beta$-thalassemia trait varies from $1 \%$ to $17 \%$ in different populations of India as revealed by many studies from India. ${ }^{[14-16]}$ The prevalence of $\beta$-thalassemia trait was $5.5 \%$ in northern India, $2.7 \%$ in western India and the overall frequency was $4.05 \% \cdot{ }^{[6]}$ Another tertiary center study from western India reported incidence of $\beta$-thalassemia trait was $11.55 \%{ }^{[14]} \mathrm{A}$ study on college, university students and pregnant women from different cities of eastern India (Kolkata, West Bengal), north east India (Dibrugarh, Assam) and southern India (Bangalore, Karnataka) showed prevalence of $\beta$-thalassemia carriers was 3.64\%, $1.48 \%$ and $2.16 \%$, respectively. ${ }^{[17]}$ Another study with 1726 cases on hemoglobinopathies in tribal population of Eastern and Northeastern India, including 463 cases from West Bengal showed the prevalence of $\beta$-thalassemia carrier of $5.18 \%$. $^{[18]}$ 
Worldwide, hemoglobin $\mathrm{E}$ thalassemia is one of the most important varieties of hemoglobinopathy. ${ }^{[1]}$ There were 1403 cases of $\mathrm{HbE}$ trait leading to a prevalence of $2.78 \%$ in the study population. Since its classic description by Chernoff et al. ${ }^{[19]}$ it has been noted to be an important public health problem in the Indian subcontinent and Southeast Asia. In a recently published report of multicenter study conducted by the Indian Council of Medical Research including Kolkata in West Bengal in the east, Dibrugarh in Assam in the north east amongst six cities included in the study, done in tertiary care centers covering mostly city based population showed the prevalence of $\mathrm{HbE}$ trait as $3.92 \%$ in Kolkata and $23.90 \%$ in Dibrugarh ${ }^{[17]}$ whereas the prevalence of $\mathrm{HbE}$ trait $(2.78 \%)$ found in the present study conducted in rural areas was lower than the earlier study. The difference in prevalence of $\mathrm{HbE}$ trait between the two studies reflects the population heterogeneity in the studies.

A total of 248 cases $(0.56 \%)$ of sickle cell trait were detected in the present study. Earlier studies by Mohanty et al. ${ }^{[17]}$ have shown a prevalence of $0.14 \%$ and $0.13 \%$ from Kolkata and Dibrugarh respectively. Recent published study from Kolkata showed only 39 cases $(0.276 \%)$ of sickle cell trait amongst 14,145 cases included in the study. ${ }^{[20]}$

The prevalence of $\mathrm{HbD}$-Punjab trait was $0.21 \%$ in the present study. Hemoglobin D (Hb D) was discovered in a family of mixed British and American-Indian origin from the Los Angeles area. ${ }^{[21]}$ Earlier studies from West Bengal by Mohanty et al. ${ }^{[17]}$ and Dolai et al..$^{[4]}$ showed a prevalence of HbD-Punjab trait of $0.2 \%$ and $0.37 \%$, respectively. Though mostly reported from Punjab and other northern states of India, ${ }^{[6]}$ the present study had shown the homozygous and heterozygous states of HbD-Punjab in $0.01 \%$ and $0.21 \%$ of cases in West Bengal.

Among the other less common variants found in the present study were 34 cases $(0.07 \%)$ of HPFH traits and 14 cases $(0.03 \%)$ of rare hemoglobin variants including 6 cases of $\mathrm{Hb}$-Lepore trait. There are few studies on HPFH in India. Only a few cases have been reported from western India and Kolkata. ${ }^{[22,23]}$ Rao et al. ${ }^{[24]}$ in a study of 800 samples, from north India reported one case each of $\mathrm{Hb}$ Lepore trait and HPFH trait. In a recent study from Kolkata, West Bengal, there was only one case of $\mathrm{Hb}$ Lepore trait and no HPFH reported. ${ }^{[20]}$

$\beta$-thalassemia major was detected in 368 cases $(0.73 \%)$ constituting majority in the group of homozygous thalassemia followed by 213 cases $(0.42 \%)$ and 75 cases $(0.15 \%)$ of HbE- $\beta$-thalassemia and $\mathrm{HbS}-\beta$-thalassemia, respectively. The first case of $\mathrm{HbE}$ disease in India was reported by Chatterjee et al. ${ }^{[25]}$ Because of the extremely high frequency of $\mathrm{HbE}$ trait within the Indian subcontinent, it is very common for individuals in this region to inherit both hemoglobin $\mathrm{E}$ and $\beta$-thalassemia. Data collected over recent years indicate that $\mathrm{HbE}-\beta$-thalassemia is causing an increasingly severe public health problem throughout the Indian subcontinent and parts of Southeast Asia. ${ }^{[26]}$ Among ethnic groups in which prevalence of $\mathrm{HbE}$ and $\beta$-thalassemia are known, there is a vast discrepancy between the reported number of cases of
$\mathrm{HbE} / \beta$-thalassemia and the number predicted by Hardy-Weinberg law. ${ }^{[27]}$ The first case of $\beta$-thalassemia/sickle cell disease in India was reported by Naik and colleagues. ${ }^{[28]}$ Though, a high prevalence of sickle cell trait $(29.8 \%)$ is reported from Orissa, ${ }^{[29]}$ only a small number of cases (heterozygous, $0.56 \%$ ) are observed in the present study giving rise to small number of compound heterozygotes (HbS- $\beta$-thalassemia, $0.15 \%$ ) where $\beta$-thalassemia trait showed the highest prevalence of $6.61 \%$.

Due to socio-cultural practices, marriages in India are usually among individuals of the same caste or ethnic group and this makes it important to know the prevalence of $\beta$-thalassemia and also $\mathrm{HbE}$ in different ethnic groups. ${ }^{[17]}$ Weatherall ${ }^{[30]}$ suggested that more detailed information on frequency and economic data is required to provide evidence for the health burden posed by thalassemias in the developing world. The programme of prevention through carrier screening and prenatal diagnosis should receive the highest priority in the future, in order to reduce drastically the birth of affected children. ${ }^{[31]}$ Diseases which are known to run in families and have high-risk of recurrence become a social stigma when nothing or very little is known about them. Illiterate populations are ignorant about the medical, social and financial burden of the disease. This further compounds the problem. ${ }^{[1]}$

The present study conducted in large rural population in West Bengal arguably reflects the different types of hemoglobinopathies prevalent in eastern part of the country.

\section{CONCLUSION}

$\beta$-thalassemia is the most common hemoglobinopathy in rural Bengal followed by $\mathrm{HbE}$. The heterogeneous population is harboring almost all major hemoglobinopathies. The prevention and control of hemoglobinopathies in the state is an uphill task for the planners, policy makers, medical and health care providers. This study, done in a large population, provides a comprehensive database on the spectrum of hemoglobinopathies in West Bengal.

\section{ACKNOWLEDGEMENT}

The authors are thankful to all the members of the Thalassaemia Society of Midnapore District, Paschim Medinipore (West Bengal, India) and especially grateful to Mr. Subhasis Nayek, Medical Laboratory Technologist for providing the necessary documents and technical help.

\section{REFERENCES}

1. Saxena A, Phadke SR. Thalassaemia control by carrier screening: The Indian scenario. Current Science 2002;83:291-5.

2. Angastiniotis M, Modell B, Englezos P, Boulyjenkov V. Prevention and control of hemoglobinopathies. Bull World Health Organ 1995;73:375-86.

3. Verma IC, Choudhry VP, Jain PK. Prevention of thalassemia: A necessity in India. Indian J Pediatr 1992;59:649-54.

4. Dolai TK, Dutta S, Bhattacharyya M, Ghosh MK. Prevalence of hemoglobinopathies in rural Bengal, India. Hemoglobin 2012;36:57-63.

5. Varawalla NY, Old JM, Sarkar R, Venkatesan R, Weatherall DJ. The spectrum of beta thalassaemia mutations on the Indian subcontinent: The basis for prenatal diagnosis. Br J Haematol 1991;78:242-7. 
6. Madan N, Sharma S, Sood SK, Colah R, Bhatia LM. Frequency of $\beta$-thalassemia and other hemoglobinopathies in northern and western India. Indian J Hum Genet 2010;16:16-25.

7. Tyagi S, Saxena R, Choudhry VP. HPLC - how necessary is it for haemoglobinopathy diagnosis in India? Indian $\mathrm{J}$ Pathol Microbiol 2003;46:390-3.

8. Shrivastav A, Patel U, Joshi JR, Kaur A, Agnihotri AS. Study of hemoglobinopathies and $\mathrm{Hb}$ variants in population of Western India using HPLC: A report of 7,000 cases. J Appl Hematol 2014;4:104-9.

9. Denic S, Agarwal MM, Al Dabbagh B, El Essa A, Takala M, Showqi S, et al. Hemoglobin A2 Lowered by Iron Deficiency and $\alpha$-Thalassemia: Should Screening Recommendation for $\beta$-Thalassemia Change? ISRN Hematol 2013;2013:858294.

10. Newton CR, Graham A, Heptinstall LE, Powell SJ, Summers C, Kalsheker N, et al. Analysis of any point mutation in DNA. The amplification refractory mutation system (ARMS). Nucleic Acids Res 1989;17:2503-16.

11. Wetherall DJ, Clegg JB. Inherited haemoglobin disorders: An increasing global health problem. Bull World Health Organ 2001;79:704-12.

12. Shrivastav A, Patel U, Joshi JR, Kaur A, Agnihotri AS. Study of hemoglobinopathies and $\mathrm{Hb}$ variants in population of Western India using HPLC:A report of 7,000 cases. J Appl Hematol 2013;4:104-9.

13. Indian Red Cross Society (IRCS), Gujarat State Branch. Annual Report 2009-2010. Ahmedabad: IRCS, Gujarat State Branch; 2010.

14. Sharma RS, Parekh JG, Shah KM. Hemoglobinopathies in wastern India. J Assoc Physicians India 1963;11:969-73.

15. Misra RC, Ram B, Mohapatra BC, Das SN, Misra SC. High prevalence and heterogenicity of thalassemias in Orissa. Indian J Med Res 1991;94:391-4.

16. Dash S. Beta thalssemia trait in the Punjab (North India). Br J Haematol 1985;61:185-6.

17. Mohanty D, Colah RB, Gorakshakar AC, Patel RZ, Master DC, Mahanta $\mathrm{J}$ et al. Prevalence of $\beta$-thalassemia and other haemoglobinopathies in six cities in India: A multicentre study. J Community Genet 2013;4:33-42.

18. De M, Halder A, Podder S, Sen R, Chakrabarty S, Sengupta B et al. Anemia and hemoglobinopathies in tribal population of Eastern and North-eastern India. Hematology 2006;11:371-3.

19. Chernoff Al, Minnich V, Nanakorn S, Tuchinda S, Kashemsant C, Bangkok, Thailand, Chernoff Rr. et al. Studies on hemoglobin E. I. The clinical, hematologic, and genetic characteristics of the hemoglobin $E$ syndromes. J Lab Clin Med 1956;47:455-89.
20. Chaudhury SR, Roy H, Bhattacharyya NK, Mondal PK, Biswas PK, Roy S. Spectrum of hemoglobin variants in Eastern Indian population; a study of 14,145 cases. Al Ameen J Med Sci 2013;6:243-8.

21. Itano HA. Third abnormal hemoglobin associated with hereditary hemolytic anemia. Proc Natl Acad Sci 1951;37:775-84.

22. Balgir RS. The burden of haemoglobinopathies in India and the challenges ahead. Curr Sci 2000;79:1536-47.

23. Sukumaran PK, Randelia HP, Merchant SM. Thalassemia syndromes in Bombay. J Indian Med Assoc 1961;9:477-88.

24. Rao S, Kar R, Gupta SK, Chopra A, Saxena R. Spectrum of haemoglobinopathies diagnosed by cation exchange HPLC and modulating effects of nutritional deficiency anaemias from north India. Indian J Med Res 2010;132:513-9.

25. Chatterjee JB, Saha AK, Ray RN, Ghosh SK. Hemoglobin E-thalassemia disease. Indian J Med Sci 1957;11:553-64.

26. Olivieri NF, Muraca GM, O'Donnell A, Premawardhena A, Fisher C, Weatherall DJ. Studies in haemoglobin $\mathrm{E}$ beta-thalassaemia. $\mathrm{Br} \mathrm{J}$ Haematol 2008;141:388-97.

27. Krishnamurti L. Few reports of hemoglobin E/beta-thalassemia in Northeast India: Underdiagnosis or complete exclusion of beta-thalassemia by hemoglobin E. J Pediatr Hematol Oncol 2000;22:558-63.

28. Naik SK, Kothari BV, Jhaveri CL, Sukumaran PK, Sanghvi LD. Fatal hemolytic anemia presumably due to the combination of sickle cell and thalassemia gene; case report. Indian J Med Sci 1957;11:244-9.

29. Balgir RS. Spectrum of Hemoglobinopathies in the State of Orissa, India: A Ten Years Cohort Study. J Assoc Physicians India 2005;53:1021-6.

30. Weatherall DJ. Keynote address: The challenge of thalassemia for the developing countries. Ann N Y Acad Sci 2005;1054:11-7.

31. Verma IC, Saxena R, Kohli S. Past, present and future scenario of thalassaemic care and control in India. Indian $\mathrm{J}$ Med Res $2011 ; 134: 507-21$

How to cite this article: Mandal PK, Maji SK, Dolai TK. Present scenario of hemoglobinopathies in West Bengal, India: An analysis of a large population. Int J Med Public Health 2014;4:496-9.

Source of Support: Nil, Conflict of Interest: The authors declared no conflicts of interest. 